\title{
Role of Monocyte-to-lymphocyte Ratio, Mean Platelet Volume-to-Platelet Count Ratio, C-Reactive Protein and Erythrocyte Sedimentation Rate as Predictor of Severity in Secondary Traumatic Brain Injury: A Literature Review
}

\author{
Tjokorda Istri Sri Dalem Natakusuma ${ }^{1}$, Tjokorda G. B. Mahadewa ${ }^{2 *}$ (i), Putu Eka Mardhika ${ }^{2}$ (D), Sri Maliawan² (iD, \\ Tjokorda Gde Agung Senapathi ${ }^{3}$, Christopher Ryalino ${ }^{3}$ (D) \\ ${ }^{1}$ Postgraduate Degree Program, Faculty of Medicine, Udayana University, Denpasar, Bali, Indonesia; ${ }^{2}$ Department of Surgery, \\ Faculty of Medicine, Udayana University, Denpasar, Bali, Indonesia; ${ }^{3}$ Department of Anesthesiology and Intensive Care, \\ Faculty of Medicine, Universitas Udayana, Denpasar, Bali, Indonesia
}

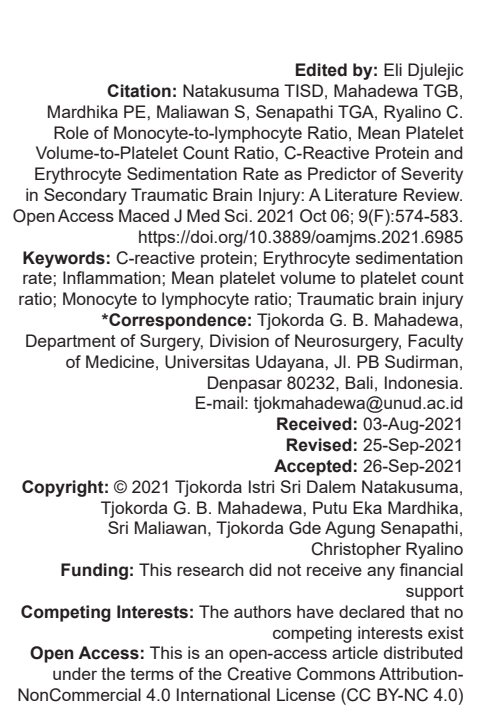

Background

Traumatic brain injury (TBI) is one of the main causes of mortality and morbidity in the world, which cause economic burden to the patients [1]. Decrease of cognitive and physical capabilities are suffered by the patient for a long time [2]. TBI is an injury to the brain and cranium which is caused by external mechanical forces and disrupts the structure and function of the brain [3]. Based on its pathophysiology, TBI is divided into primary and secondary TBI [4]. Primary TBI is injury that is caused directly by the mechanical forces to the brain tissue (axon, vascular, and glial cell). Secondary $\mathrm{TBI}$ is injury to the brain following primary TBI because of neuroinflammation as consequences of neuronal and glial cell injury which cause release of various inflammation cytokine and chemokine [5]

The process of secondary TBI is preventable and treatable. Secondary TBI is an important window of therapy and can determine prognosis of progression and recovery of $\mathrm{TBI}[5]$. In this manner, appropriate initial management is required, including biomarker examination to predict the severity of secondary TBI. In this way, viability of the treatment could be improved and secondary TBI can be avoided.

Level of inflammatory cells and biomarkers such as C-reactive protein (CRP) and erythrocyte sedimentation rate (ESR) can be used as indicator of increased systemic inflammatory response [6], [7]. However, CRP and ESR are not routinely performed in trauma patients despite its widely used in assessing 
inflammatory disease. Complete blood count (CBC) is more routinely performed, easily available, and cheaper than CRP and ESR. In CBC, monocyte and platelet count (PC) can be obtained [8].

\section{Secondary TBI}

The pathophysiology of $\mathrm{TBI}$ is divided into primary and secondary TBI. Primary TBI occurs because of direct mechanical force on the head which causes damage to the integrity of brain cells. The trauma can be focal or diffuse due to stretching mechanism of brain structures [9], [10], [11]. Secondary TBI is injury that is occurred following primary injury. Secondary TBI is associated with inflammatory reactions, oxidative stress, neural excitotoxicity, impaired ion balance and massive release of neurotransmitters and mitochondrial dysfunction in the brain which can lead to progressive neuronal cell death [9], [12], [13].

Secondary $\mathrm{TBI}$ occurs within hours to days following primary $\mathrm{TBI}$ and worsens the injury that has already occurred. Secondary TBI develops mainly because of glial and neuronal cell dysfunction, metabolic disturbances, neuroinflammation, and brain swelling. All of these processes lead to various disturbances such as blood brain barrier (BBB) disruption, mitochondrial dysfunction, oxidative stress, and hypoperfusion to the brain tissue. Secondary TBI can have a more severe impact to the brain compared to primary TBI. However, secondary TBI is also a potential target in treating brain injury [14].

Following primary TBI, a severe inflammatory response is occurred. This process begins with the activation and migration of leukocytes around the damaged tissue. Activation of leukocytes causes pro-inflammatory mediators release such as cytokines interleukin (IL)-6, IL-1 $\beta$, and chemokines released by microglia, immune cells, and neurons in surrounding tissues. All of these immune processes lead to astrogliosis. The presence of blood product and reactive oxygen species in extravascular space also initiates the inflammation [10], [15], [16].

The inflammatory response can exert a neuroprotective effect as well as exacerbating an already existing injury. The inflammatory response is important for clearing the damage effect of trauma and remodeling preparation. Long-lasting inflammatory processes can have neurotoxic effects, increase oxidative stress, apoptosis, and neuronal excitotoxicity [10], [17]. Activation of neuron due to brain injury can cause the release of various neuropeptides such as neurokinin $A$, neurokinin $B$, and substance $P$, which can cause neuroinflammation. The neuroinflammation increases leukocyte migration into the central nervous system environment, one of which is by expressing chemotactic effects on monocytes and neutrophils [10], [15].
The initiation of neuroinflammation following $\mathrm{TBI}$ is a complex process and involves many factors such as inflammatory cytokines and chemokines as well as anti-inflammatory factors [11]. The neuroinflammation that occurs is capable to regenerate and restore the tissue function. However, if it is activated excessively, it can cause further brain injury [18].

\section{Role of Monocyte in Secondary TBI}

Monocyte is a progenitor cell that has an important role in the pathophysiology of secondary TBI. Monocyte increases the concentration of macrophage in certain tissue. Monocyte is also considered could performed harmonization of immune processes that are occurred following trauma [19]. Macrophages, which are monocyte derivatives, are capable of producing growth factors and neuroprotective factors including IGF-1, BDNF, GDF15, vascular endothelial growth factor, and angiogenin [20]. Macrophages can trigger remodeling of damaged tissue and regeneration. However, excessive pro-inflammatory activity by macrophage in a long time can cause further injury to the affected tissue [15].

TBI activates microglia that leads to infiltration of neutrophils, lymphocytes and monocytes which will further differentiate into macrophages [11], [17]. Monocytes accumulate in the injured area up to 3 days after the onset of TBI and cause neurotrophic and neurotoxic effects [21], [22]. Activation of many proinflammatory cytokines attracts more immune cells and increases neuroinflammation following TBI. Monocytes in the injured area secretes pro-inflammatory cytokines such as IL-1- $\beta$, tumor necrosis factor (TNF)- $\alpha$, IL-6, IL-8, and interferon- $\gamma$ [23]. TNF- $\alpha$ and IL-1 are the initial proinflammatory cytokine released following trauma. Both of these cytokines are short-lived, $20 \mathrm{~min}$ and $6 \mathrm{~min}$, respectively [24]. These pro-inflammatory cytokines stimulate other immune cells to induce secretion of other pro-inflammatory cytokines such as IL-6 and IL-8, and the anti-inflammatory cytokine IL-10 [25], [26].

Under normal conditions, the brain is considered an exclusive organ that is difficult to reach even by host immune system. The presence of the BBB makes it difficult for immune cells to infiltrate the brain. The BBB is formed by endothelial cells, tight junctions, pericytes, and astrocytes. It maintains homeostasis in the brain environment. The BBB prevents the neurotoxic components of plasma and blood cells. It also regulates the transport of various molecules, including circulating immune cells, in and out of the brain environment [11].

In brain injury, damage and dysfunction of the BBB can occur, causing plasma leakage and infiltration of blood cell components into the central nervous system [14], [27], [28]. The BBB disruption resulting from $\mathrm{TBI}$ allows monocytes to enter the 
brain environment [19]. Monocytes begin to enter the perivascular space within 1-2 days after trauma, then differentiate into macrophages and persist for several weeks after trauma. CCL2 is a chemokine that attracts monocyte to infiltrate inflammation site. This chemokine is produced by epithelial cells of the choroid plexus following TBI [15].

One of the mechanisms of BBB disruption is an increase in aquaporin (AQP)1 and $A Q P 4$ regulations that can increase water transfer between cells [14]. Monocyte increases AQP4 expression which regulates extracellular fluid in the brain and reduced monocyte can cause disturbance in the process of resolution of vasogenic edema [20], [29]. Accumulation of fluid in intracellular or extracellular space in the brain leads to cerebral edema. Excessive cerebral edema leads to increase intracranial pressure because of limited intracranial cavity. Cerebral edema is an important pathology in head injury patients because it can disrupt perfusion and oxygenation to the brain, which eventually cause ischemic following TBI [30].

The neuroinflammation process triggers damage from BBB and infiltration of brain tissue by blood cells and edema and activation of immunocompetent cells and chemotactic factors. One of the most common pathological findings in this condition is the large number of leukocyte cells (monocytes and neutrophils). Leukocytes that invade BBB produce cytokines - good pro-inflammatory cytokines and do not participate in the BBB disruption process [31].

Monocyte plays an important role in maintaining permeability of BBB. Disruption of the BBB due to trauma causes BBB permeability disorders and its recovery is very dependent on microglia activity. Activation of microglia itself depends on peripheral macrophage. Therefore, increased monocytes as a macrophage progenitor become very important in the repairment process of BBB [32]. Macrophages are known to produce matricellular glycoprotein osteopontin which can induce extensions of astrocyte into the infarct area and contributes to the improvement of blood circulation [20].

Hypoxia can occur due to an imbalance between supply and demand for oxygen in certain tissues. Hypoxia is a common process in both acute and chronic inflammatory conditions. Monocytes can adapt well to a hypoxic environment. This can be done by converting oxidative metabolic processes into glycolysis [33]. Monocytes also increase proliferation in a hypoxic environment. Under a hypoxic environment, monocytes adapt by transcribing the HIF factor. One of the important responses in hypoxic tissues is angiogenesis, which occurs as a compensatory response to improved perfusion to these tissues. Macrophages have a major function in angiogenesis process where HIF-2a is the main mediator in the angiogenesis process [33]. Low levels of monocytes/macrophages can be correlated with the severity of the inflammatory process in ischemic brain lesions. Macrophages that infiltrate ischemic lesions are neuroprotective by increasing the antiinflammatory response so as to prevent a prolonged inflammatory process [34].

\section{Roles of Lymphocytes in Secondary Brain Injury}

Hormone cortisol is released during high stress response such as traumatic injury. The high cortisol level in the body can lead to lymphopenia [35]. Uncontrolled inflammation increases level of stress, therefore increased level of cortisol and leads to the lower lymphocyte count. In the other hand, appropriate and stable immune response can be reflected by higher lymphocyte count [36]. Lymphocyte level is a reflection of a more controlled inflammation and less damage because of lymphocyte-mediated apoptosis [8]. Therefore, low lymphocyte count following TBI is a reflection of worsening or uncontrolled neuroinflammation that leads to worsening of secondary TBI.

\section{Role of platelets in secondary brain injury}

Thrombocytes have a major function in the process of inflammation [7]. Platelets can be a reflection of pro-inflammatory and prothrombotic conditions in the pathophysiological process of a disease [37]. Platelets can be classified as innate immune cells because in addition to functioning as hemostatic agents, platelets are also able to recognize pathogens and attract other immune cells such as neutrophils, macrophages, and lymphocytes to the affected site [38], [39]. Inflammation process through inflammatory cells and pro-inflammatory cytokine such as IL-6 has ability to deform the thrombocyte and increase the reactivity of thrombocyte [40].

Hemostasis or balancing of coagulation and anticoagulation is a dynamic process and thrombocytes have major function in hemostasis maintenance. Low activity of thrombocyte leads to disturbance of coagulation and eventually causes hypocoagulation and bleeding [41], [42]. Hemostasis is occurred following activation of platelets through adhesion, aggregation, and secretion phase. Adhesion is a process of platelet adhesion to injured endothelia. Shape change is occurred following platelet adhesion and leads to conformation changes in GPIIb-IIla. Aggregation occurs due to conformational changes if GPIlb-Illa which enhances the platelet plug formation. In secretion phase, thrombocyte releases granule which leads to increased P-selectin expression on its surface. Moreover, platelets also increase activation of coagulation cascade [43], [44]. 
Thrombocyte production (thrombopoiesis) is controlled by thrombopoietin and several inflammation mediators, such as IL-1, IL-3, IL-6, GM-CSF, and TNF- $\alpha$ [42], [45]. Thrombopoietin is produced in the liver by the parenchymal and sinusoidal endothelial cells [46], [47]. The inflammatory process that occurs in head injured patients can cause platelet activation and increase platelet production [31], [48]. Thrombopoietin is increased following TBI due to increased IL- 6 because of neuroinflammation [46], [47], [49]. In trauma patients, thrombopoietin correlate positively with reactivity of platelet and increasing PC [50]. Thrombopoiesis during acute inflammation cause increasing production of large thrombocyte (megakaryocytes) which reflect as thrombocytosis in CBC [8]. Several inflammatory mediators have been identified that correlate with increased PC, which are CRP, TNF- $\alpha, \mathrm{IL}-1$, and IL-6 [51], [52].

Thrombopoiesis increase thrombocyte quantity in circulation in form of large and very reactive thrombocyte that attracted to the inflammation site [8], [53]. Active thrombocytes increase pro-inflammatory cytokine release and had effect to other inflammation cells such as neutrophils, macrophages, and T-lymphocytes [54], [55]. In addition, platelets also actively participate by playing a role in increasing the accumulation of leukocytes in inflamed tissues and assisting the process of leukocyte migration in blood vessel walls [38]. These processes initiate and cause worsening of neuroinflammation [54], [55].

Platelets themselves contribute to the inflammatory process through the arachidonic acid (AA) cascade [56]. Following trauma, the thrombocyte can be malfunction due to trauma-induced platelet dysfunction. Trauma-induced platelet dysfunction is a condition when platelets are not responding to its agonist. Activation of platelets can be achieved through several different pathways, including stimulation by adenosine diphosphate (ADP) and AA [57], [58]. ADP could activate thrombocyte directly while AA could activate thrombocytes indirectly. ADP directly binds to receptors such as $\mathrm{P} 2 \mathrm{Y} 1, \mathrm{P} 2 \mathrm{Y} 12$, and/or $\mathrm{P} 2 \mathrm{X} 1$ on platelet membrane to activate thrombocyte. In the other hand, AA convert to thromboxane $A_{2}$ (TxA2) by the cyclooxygenase pathway before it can activate platelets. Increase in $\mathrm{Ca}^{2+}$ influx occurs after binding process between the agonist and its receptors. Platelets also deform to increase the surface, therefore, increase interactions between platelet and endothelial [59].

Following $\mathrm{TBI}$, platelet has a temporary disturbed response to $A A$ which is the characteristic of platelet dysfunction [60]. This finding explains longer bleeding time and tendency of oozing after TBI. This is a reflection of cyclooxygenase and thromboxane TxA2 receptor disturbance. This phenomenon is hypothetically caused by presence of unknown substance in plasma that inhibits platelet following
TBI. Another possibility is hyperactivation of platelet in injured brain blood vessel leads to exhaustion and cause platelet to be in a refractory state [60]. In addition, inhibition of ADP is also a theory of platelet dysfunction in severe trauma [61]. Decreased ability of ADP to activate platelets is correlated with lower survival rate in TBI patients [62]

In severe trauma patients, there is increased activity of platelets. Risk of thrombosis is increases due to increased activity of platelet. Trauma activates coagulation cascade and generate thrombin which activates C5a complement system. Activation of the complement system further activates the response immune system following trauma [63]. Because of this mechanism, severe trauma leads to hypercoagulable state and increased immune response [41], [42]. Severe trauma can lead to activation of the protein $C$ pathway which has antithrombotic and antiinflammatory effects and eventually cause acute traumatic coagulopathy [64].

The brain contains high tissue factor (TF) which is a cofactor for factor VIla in the extrinsic coagulation cascade [65], [66]. In TBI pathophysiology, TF is released following trauma and activate coagulation pathway [67], [68], [69]. Replacement of tissue thromboplastin activate extrinsic cascade to form fibrin clot [60], [70]. Furthermore, injured cerebrovascular structure activates thrombocyte because of endothelial disruption. Active thrombocytes activate intrinsic cascade to formed intravascular thrombosis due to vascular inflammation [60], [70]. It occurs because active platelet causes activation of TxA2 and procoagulant proteins such as P-selectin and glycoprotein IIA which can cause adhesion of platelet and cause thrombosis [71].

This phenomenon can overstimulated and consume platelets, rendering them desensitized to agonists for a time. Alternatively, thrombin degrades cyclooxygenase, an enzyme required for conversion of $A A$ to TxA2 [72]. This leads to platelets being nonresponsive to $\mathrm{AA}$ stimulation. Overactivation of coagulation leads to consumptive coagulopathy and decreased of hyperactive platelet [73], [74]. In the other hand, to maintain the hemostasis balance, plasmin is activated and causing fibrinolysis and clot lysis [60].

Yolcu et al. found association between trauma severity and level of platelet [25]. Other study by Jacoby et al. reported that activation of platelet and its function is usually occurred following severe injury. Increased activation of platelet combines with decreased of its major function was reported associate with increased mortality [75], [76].

\section{Monocyte-to-Lymphocyte Ratio (MLR)}

Monocyte count is a reflection of innate immunity while lymphocyte count is a reflection of 
adaptive immunity. Therefore, MLR is an indicator of immunity balance between innate and adaptive immunity. The magnitude of neuroinflammation can be reflected in MLR value, whereas higher MLR reflect more severe secondary injury.

MLR is a fairly new parameter to be used as a marker of inflammatory response. MLR itself has been proven to be accurate as a factor in the severity and prognosis of various diseases such as tuberculosis and coronary heart disease [77], [78]. Jan et al. also found that MLR can be used as a prognostic factor for malignancy [78]. Sheng et al. suggested that MLR is a predictor of the inflammatory process and the risk of hematoma expansion in cases of cerebral contusion after brain injury [79]. In stroke patients, MLR was reported associated with depression occurrence within 3 months [80].

\section{Mean Platelet Volume-to-PC Ratio (MPV-PCR)}

The MPV is a laboratory parameter that showing function and activation of platelet [42], [81]. The MPV is showing average size of thrombocytes in plasma which ranging between 9.7 and $12.8 \mathrm{fl}$ typically. The MPV can be increased because of presence of larger and hyperactive thrombocytes from spleen. The MPV can also decreased mainly because of consumption of larger and more brittle thrombocytes [82], [83].

The MPV has been considered as inflammation marker and widely used to assess inflammation in inflammatory bowel disease, asthma, and chronic obstructive pulmonary disease [84], [85], [86]. MPV is considered as marker of inflammation in trauma patients [25]. Lippi et al. reported severity of mild head trauma was associate parallelly with the lower MPV [82].

MPV is an indicator of inflammation and prothrombotic conditions because thrombopoiesis is regulated by thrombopoietin and several proinflammatory cytokines (IL-1, IL-6, and TNF- $\alpha$ ) [42]. In addition to their function in hemostasis, platelets can amplify the inflammation response that occurs in various diseases [84]. The function of thrombocyte is determined by its size and age. Larger thrombocytes are considered younger, more active, and aggregable than the smaller ones [25], [87]. Larger thrombocytes contain more granules and produce more TxA2. They also secrete more serotonin and $\beta$-thromboglobulin [25]. The volume of platelet can be interfered by cytokines and acute phase reactant. Megakaryopoiesis process can be inhibited by accumulation of pro-inflammation cytokine and acute-phase reactants. The inhibited megakaryopoiesis causes release of small volume platelet to the circulation [25]. In acute inflammation, large platelet is required due to its ability to release pro-inflammatory cytokines and thrombotic agents. They are also more active compare do smaller one [25], [42]. Lippi et al. reported severity of mild head trauma was associated parallelly with lower MPV [82]. MPV is considered as marker of inflammation in trauma patients [25].

PC itself was found to be reduced in various severe diseases such as heart infarction and various liver diseases such as liver cirrhosis [88]. The increase in MPV was found to be inversely proportional to PC levels, so that the increase in the ratio of MPV and PC was considered to describe the severity of a particular disease, one of which was in cases of deep vein thrombosis [81].

Thrombocytopenia is one of predictor of mortality in severe TBI [89]. PC was reported low in TBI and more reduced at day 3 post-trauma [60], [90]. Lippi et al. reported patients with mild TBI exhibit lower PC that is accompanied by lesser MPV [82]. Cortiana et al. reported that average platelet number remained low for 5 days following onset of TBI and began to increase on day $6^{\text {th }}$ [91]. Auer also reported that thrombocytopenia occurs within 1 week in TBI patients and more decreased in non-survivors [92].

Regarding role of MPV-PC ratio to CNS condition, Ray et al. reported that MPV-PC ratio can predict delayed cerebral ischemia occurrence following spontaneous subarachnoid hemorrhage. The occurrence of delayed cerebral ischemia was thought as result of platelet associated thrombogenicity [93]. Based on what have been described, MPV-PC ratio is a parameter of thrombosis event following primary TBI, beside indicator of neuroinflammation. The thrombosis event following $\mathrm{TBI}$ is considered as secondary insult that can cause more severe secondary TBI.

\section{CRP}

CRP is an acute phase reactant that synthesize in liver [94]. It is part of pentraxin family of calcium-dependent ligand-binding plasma proteins, which activate the classic complement pathway. They bind to the phosphocholine that is expressed on the surface of dead or dying cells to activate complement pathway [95], [96]. CRP production is stimulated by several factors such as infection, inflammation, stress response, tissue necrosis, trauma, and malignancy [97], [98]. While CRP is produced primarily by hepatocytes, it can be generated by human neurons [99]. CRP synthesis is induced mainly by IL-6 and increased by IL-1 $\beta$ and TNF- $\alpha$ [100], [101].

Severe TBI cause neuroinflammation which is indicated by activation of microglia and astrocyte, disruption of BBB and increase of pro-inflammatory cytokine, which are IL-1, IL-6, and TNF- $\alpha$. It eventually resulted in neuron damage. The damage of neuron increases production of IL-6 which stimulate production of CRP in liver [102]. CRP is elevated in the first 2 weeks after $\mathrm{TBI}$, proportional to the severity of systemic injury and more so in subjects with intracranial lesions on CT or MRI scans [103]. 
Increased of CRP is proven as predictor of poor outcome in head injured patients whereas higher CRP indicate more severe secondary TBI [104]. CRP level was also reported associated with level of consciousness assessed by GCS score [105]. Bomba et al. reported that CRP is possible to be used as predictor of SIRS in severe TBI which predict poor prognosis [102]. Intensive care length of stay and mechanical ventilation duration was associated with level of CRP [106], [107]. Traumatic SAH volume and presence of vasospasm induced a significant CRP response [105], [108], [109]. The presence of blood and higher clot volume was associated with increased CRP [99]. Prognostically, CRP measured through the first 2 weeks post-injury was significantly higher in subjects with poorer outcome (death or severe disability) compared to favorable outcome (GOSE > 5) at 6 months [103].

\section{ESR}

The ESR is a laboratory parameter that indicates the rate of erythrocyte sedimentation or settle in the plasma from blood specimens that has been given anti coagulation in a period of time (usually $60 \mathrm{~min}$ ), so they have units of millimeters $(\mathrm{mm})$ per hour [110]. The rate of erythrocyte sedimentation in plasma is influenced by the levels of acute-phase reactant proteins. Therefore, ESR is used to assess the acute-phase response to an inflammation process [111].

Various inflammation biomarkers that are more sensitive and specific have been found. However, ESR still can be used in assessing various diseases such as autoimmune diseases as the basis for diagnostic criteria [111]. Despite its sensitivity and specificity, ESR has been widely used mainly because of its simplicity, inexpensive, and familiarity to many practitioners [112]. ESR is reported increase in acute ischemic stroke and reflected the severity of local brain damage [113]. In head injured patients, ESR level does not increase significantly in the acute phase of inflammation but last longer when compared to CRP which is other acute-phase reactant protein [48]. It also a parameter of thrombosis event following primary TBI which is considered as secondary insult that can cause more severe secondary TBI.

\section{Conclusion}

Increased monocyte count and platelet volume followed by decreased lymphocyte and $P C$ are reflection of neuroinflammation severity following TBI. High level of CRP and high ESR are also indicator of inflammation severity following TBI. Therefore, MLR, MPV-PCR, CRP, and ESR could be predictor of severity in secondary TBI.

\section{Author Contribution}

All authors contribute equally in the making process of this article.

\section{References}

1. Roozenbeek B, Maas Al, Menon DK. Changing patterns in the epidemiology of traumatic brain injury. Nat Rev Neurol. 2013;9(4):231-6. https://doi.org/10.1038/nrneurol.2013.22 PMid:23443846

2. Shi HY, Hwang SL, Lee KT, Lin CL. Temporal trends and volumeoutcome associations after traumatic brain injury: A 12-year study in Taiwan. J Neurosurg. 2013;118(4):732-8. https://doi. org/10.3171/2012.12.jns12693

PMid:23350773

3. Williams $\mathrm{OH}$, Tallantyre EC, Robertson NP. Traumatic brain injury: Pathophysiology, clinical outcome and treatment. J Neurol. 2015;262(5):1394-6. https://doi.org/10.1007/ s00415-015-7741-4

PMid:25904204

4. Werner JK, Stevens RD. Traumatic brain injury: Recent advances in plasticity and regeneration. Curr Opin Neurol. 2015;28(6):565-73. https://doi.org/10.1097/ WCO.0000000000000265

PMid:26544030

5. Liu YW, Li S, Dai SS. Neutrophils in traumatic brain injury (TBI): Friend or foe? J Neuroinflammation. 2018;15(1):146. https://doi. org/10.1186/s12974-018-1173-X

PMid:29776443

6. Walsh KB, Sekar P, Langefeld CD, Moomaw CJ, Elkind MS, Boehme AK, et al. Monocyte count and 30-day case fatality in intracerebral hemorrhage. Stroke. 2015;46(8):2302-4. https:// doi.org/10.1161/strokeaha.115.009880

PMid:26130090

7. Pan L, Du J, Li T, Liao H. Platelet-to-lymphocyte ratio and neutrophil-to-lymphocyte ratio associated with disease activity in patients with Takayasu's arteritis: A case-control study. BMJ Open. 2017;7(4):e014451. https://doi.org/10.1136/ bmjopen-2016-014451

PMid:28473512

8. Azab B, Shah N, Akerman M, McGinn JT Jr. Value of platelet/ lymphocyte ratio as a predictor of all-cause mortality after nonST-elevation myocardial infarction. J Thromb Thrombolysis. 2012;34(3):326-34. https://doi.org/10.1007/s11239-012-0718-6 PMid:22466812

9. Pearn M, Niesman I, Egawa J, Sawada A, Almenar-Queralt A Shah SB, et al. Pathophysiology associated with traumatic brain injury: Current treatments and potential novel therapeutics. Cell Mol Neurobiol. 2016;37(4):571-85. https://doi.org/10.1007/ s10571-016-0400-1

PMid:27383839

10. Corrigan F, Mander K, Leonard A, Vink R. Neurogenic inflammation after traumatic brain injury and its potentiation of classical inflammation. J Neuroinflammation. 2016;13(1):264. https://doi.org/10.1186/s12974-016-0738-9 PMid:27724914

11. Finnie J. Neuroinflammation: Beneficial and detrimenta effects after traumatic brain injury. Inflammopharmacology. 
2013;21(4):309-20. https://doi.org/10.1007/s10787-012-0164-2 PMid:23296919

12. Zhu H, Wang Z, Yu J, Yang X, He F, Liu Z, et al. Role and mechanisms of cytokines in the secondary brain injury after intracerebral hemorrhage. Prog Neurobiol. 2019;178:101610. https://doi.org/10.1016/j.pneurobio.2019.03.003

PMid:30923023

13. Winkler E, Minter D, Yue J, Manley G. Cerebral edema in traumatic brain injury. Neurosurg Clin North Am. 2016;27(4):473-88. http:// doi.org/10.1016/j.nec.2016.05.008

PMid:27637397

14. Sulhan S, Lyon K, Shapiro L, Huang J. Neuroinflammation and blood-brain barrier disruption following traumatic brain injury: Pathophysiology and potential therapeutic targets. J Neurosci Res. 2018;98(1):19-28. http://doi.org/10.1002/jnr.24331 PMid:30259550

15. Jassam Y, Izzy S, Whalen M, McGavern DB, El Khoury J. Neuroimmunology of traumatic brain injury: Time for a paradigm shift. Neuron. 2017;95(6):1246-65. http://doi.org/10.1016/j. neuron.2017.07.010 PMid:28910616

16. Anthonymuthu T, Kenny E, Lamade A, Kagan VE, Bayır H Oxidized phospholipid signaling in traumatic brain injury. Free Rad Biol Med. 2018;124:493-503. http://doi.org/10.1016/j. freeradbiomed.2018.06.031

PMid:29964171

17. Simon D, McGeachy M, Bayır H, Clark RS, Loane DJ, Kochanek PM. The far-reaching scope of neuroinflammation after traumatic brain injury. Nat Rev Neurol. 2017;13(3):171-91. http://doi.org/10.1038/nrneurol.2017.13

PMid:28186177

18. Plesnila N. The immune system in traumatic brain injury. Curr Opin Pharmacol. 2016;26:110-7. http://doi.org/10.1016/j. coph.2015.10.008 PMid:26613129

19. Murray P. Immune regulation by monocytes. Semin Immunol. 2018;35:12-8. http://doi.org/10.1016/j.smim.2017.12.005 PMid:29290545

20. Gliem M, Schwaninger M. Jander S. Protective features of peripheral monocytes/macrophages in stroke. Biochim Biophys Acta. 2016;1862(3):329-38. http://doi.org/10.1016/j. bbadis.2015.11.004 PMid:26584587

21. Hsieh C, Kim C, Ryba B, Niemi EC, Bando JK, Locksley RM, et al. Traumatic brain injury induces macrophage subsets in the brain. Euro J Immunol. 2013;43(8):2010-22. http://doi. org/10.1002/eji.201243084

PMid:23630120

22. Morganti J, Jopson T, Liu S, Riparip LK, Guandique CK, Gupta N, et al. CCR2 antagonism alters brain macrophage polarization and ameliorates cognitive dysfunction induced by traumatic brain injury. J Neurosci. 2015;35(2):748-60. http://doi. org/10.1523/JNEUROSCI.2405-14.2015

PMid:25589768

23. Svoboda P, Kantorova I, Ochmann J. Dynamics of interleukin 1,2 , and 6 and tumor-necrosis factor alpha in multiple trauma patients. J Trauma. 1994;36(3):336-40. http://doi. org/10.1097/00005373-199403000-00009

PMid:8145312

24. Ferguson $\mathrm{KL}$, Taheri $\mathrm{P}$, Rodriguez J, Tonapi V, Cardellio A, Dechert R. Tumor necrosis factor activity increases in the early response to trauma. Acd Emerg Med. 1997;4:1035-40. http:// doi.org/10.1111/j.1553-2712.1997.tb03676.x

PMid:9383488
25. Yolcu S, Beceren GN, Tomruk O, Doguc DK, Balbaloglu O. Can mean platelet volume levels of trauma patients predict severity of trauma? Platelets. 2014;25(4):279-84. http://doi.org/10.3109/ 09537104.2013 .809410

PMid:23855431

26. Nast-Kolb D, Waydhas C, Gippner-Steppert C, Schneider I, Trupka A, Ruchholtz S, et al. Indicators of the posttraumatic inflammatory response correlate with organ failure in patients with multiple injuries. J Trauma. 1997;42(3):446-54; discussion 454-5. http://doi.org/10.1097/00005373-199703000-00012 PMid:9095112

27. Sweeney M, Zhao Z, Montagne A, Nelson AR, Zlokovic BV. Blood-brain barrier: From physiology to disease and back. Physiol Rev. 2019;99(1):21-78. http://doi.org/10.1152/ physrev.00050.2017

PMid:30280653

28. Hubbard W, Dong J, Cruz M, Rumbaut R. Links between thrombosis and inflammation in traumatic brain injury. Thrombosis Res. 2021;198:62-71. http://doi.org/10.1016/j. thromres.2020.10.041 PMid:33290884

29. Nagelhus EA, Ottersen OP. Physiologic roles of aquaporin-4 in brain. Physiol Rev. 2013;93(4):1543-62. http://doi.org/10.1152/ physrev.00011.2013 PMid:24137016

30. Qureshi A, Suarez J. Use of hypertonic saline solutions in treatment of cerebral edema and intracranial hypertension. Crit Care Med. 2000;28(9):3301-13. http://doi. org/10.1097/00003246-200009000-00032 PMid:11008996

31. Stamatovic SM, Dimitrijevic OB, Keep RF, Andjelkovic AV. Inflammation and brain edema: new insights into the role of chemokines and their receptors. Acta Neurochir Suppl. 2006;96:444-50. http://doi.org/10.1007/3-211-30714-1_91 PMid:16671502

32. Aertker B, Kumar A, Prabhakara KS, Smith P, Furman NE, Hasen $\mathrm{X}$, et al. Pre-injury monocyte/macrophage depletion results in increased blood-brain barrier permeability after traumatic brain injury. J Neurosci Res. 2019;97(6):698-707. http://doi.org/10.1002/jnr.24395 PMid:30746753

33. Strehl C, Fangradt $M$, Fearon $U$, Gaber $T$, Buttgereit $F$ Veale DJ. Hypoxia: How does the monocyte-macrophage system respond to changes in oxygen availability? J Leuko Biol. 2013;95(2):233-41. http://doi.org/10.1189/jlb.1212627 PMid:24168857

34. Perego C, Fumagalli S, Zanier E, Carlino E, Panini N, Erba E, et al. Macrophages are essential for maintaining a M2 protective response early after ischemic brain injury. Neurobiol Dis. 2016;96:284-93. http://doi.org/10.1016/j.nbd.2016.09.017 PMid:27697537

35. Thomson SP, McMahon LJ, Nugent CA. Endogenous cortisol: A regulator of the number of lymphocytes in peripheral blood Clin Immunol Immunopathol. 1980;17(4):506-14. http://doi. org/10.1016/0090-1229(80)90146-4

PMid:7192197

36. Zouridakis EG, Garcia-Moll X, Kaski JC. Usefulness of the blood lymphocyte count in predicting recurrent instability and death in patients with unstable angina pectoris. Am J Cardiol. 2000;86(4):449-51. http://doi.org/10.1016/ s0002-9149(00)00963-2

PMid:10946041

37. Gasparyan AY, Ayvazyan L, Mikhailidis DP, Kitas GD. Mean platelet volume: A link between thrombosis and inflammation? Curr Pharm Des. 2011;17(1):47-58. http://doi. 
org/10.2174/138161211795049804

PMid:21247392

38. Nurden A. The biology of the platelet with special reference to inflammation wound healing and immunity. Front Biosci. 2018;23(2):726-51. http://doi.org/10.2741/4613 PMid:28930569

39. Dukhinova M, Kuznetsova I, Kopeikina E, Veniaminova E, Yung AW, Veremeyko $\mathrm{T}$, et al. Platelets mediate protective neuroinflammation and promote neuronal plasticity at the site of neuronal injury. Brain Behavior Immun. 2018;74:7-27. http://doi. org/10.1016/j.bbi.2018.09.009

PMid:30217533

40. Van der Loo B, Martin JF. A role for changes in platelet production in the cause of acute coronary syndromes. Arterioscler Thromb Vasc Biol. 1999;19(3):672-9. http://doi.org/10.1161/01. atv.19.3.672

PMid: 10073972

41. Owings JT, Bagley M, Gosselin R, Romac D, Disbrow E. Effect of critical injury on plasma antithrombin activity: Low antithrombin levels are associated with thromboembolic complications. J Trauma. 1996;41:396-406. http://doi. org/10.1097/00005373-199609000-00004

PMid:8810955

42. Miller RS, Weatherford DA, Stein D, Crane MM, Stein M Antithrombin III and trauma patients: Factors that determine low levels. J Trauma. 1994;37:442-5.

PMid:8083907

43. Andrews RK, Lopez JA, Berndt MC. Molecular mechanisms of platelet adhesion and activation. Int $\mathrm{J}$ Biochem Cell Biol. 1997;29(1):91-105. http://doi.org/10.1016/ s1357-2725(96)00122-7

PMid:9076944

44. Walsh PN, Griffin JH. Contributions of human platelets to the proteolytic activation of blood coagulation factors XII and XI. Blood. 1981;57(1):106-18.

PMid:7004531

45. Kaushansky K. The molecular mechanisms that control thrombopoiesis. J Clin Invest. 2005;115(12):3339-47. http://doi. org $/ 10.1172 / \mathrm{JCl} 26674$ PMid:16322778

46. Kalish $\mathrm{H}$, Phillips TM. Application of immunoaffinity capillary electrophoresis to the measurements of secreted cytokines by cultured astrocytes. J Sep Sci. 2009;32(10):1605-12. http://doi. org/10.1002/jssc.200900047

PMid:19472286

47. Kaushansky K. Lineage-specific hematopoietic growth factors. N Engl J Med. 2006;354(19):2034-45. http://doi.org/10.1056/ NEJMra052706

PMid:16687716

48. Kusuma G, Maliawan S, Mahadewa T, Senapathi TG, Lestari AA, Muliarta IM. Neutrophil-to-lymphocyte ratio and platelet-tolymphocyte ratio correlations with C-reactive protein and erythrocyte sedimentation rate in traumatic brain injury. Open Access Macedonian J Med Sci. 2020;8(B):1185-92. https://doi. org/10.3889/oamjms.2020.5544

49. Loane DJ, Kumar A. Microglia in the TBI brain: The good, the bad, and the dysregulated. Exp Neurol. 2016;275(3):316-27. http://doi.org/10.1016/j.expneurol.2015.08.018

PMid:26342753

50. Miyazaki $\mathrm{H}$, Kato $\mathrm{T}$. Thrombopoietin: Biology and clinical potentials. Int J Hematol. 1999;70(4):216-25.

PMid:10643146

51. Alexandrakis MG, Passam FH, Perisinakis K, Ganotakis E, Margantinis G, Kyriakou DS, et al. Serum proinflammatory cytokines and its relationship to clinical parametes in lung cancer patients with reactive thrombosytosis. Respir Med. 2002;96(8):553-8. http://doi.org/10.1053/rmed.2002.1328 PMid:12195834

52. Alexandrakis MG, Passam FH,MoschandrealA, ChristophoridouAV Pappa CA, Coulocheri SA, et al. Levels of serum cytokines and acute phase proteins in patients with essential and cancerrelated thrombocytosis. Am J Clin Oncol. 2003;26(2):135-40. http://doi.org/10.1097/00000421-200304000-00007 PMid: 12714883

53. Thompson CB, Jakubowski JA. The pathophysiology and clinica relevance of platelet heterogeneity. Blood. 1988;72(1):1-8. PMid:3291975

54. Kim CH, Kim SJ, Lee MJ, Kwon YE, Kim YL, Park KS, et al. An increase in mean platelet volume from baseline is associated with mortality in patients with severe sepsis or septic shock. PLos One. 2015;10(3):e0119437. http://doi.org/10.1371/journal. pone. 0119437

PMid:25742300

55. Nording HM, Seizer P, Langer HF. Platelets in inflammation and atherogenesis. Front Immunol. 2015;6:98. http://doi. org/10.3389/fimmu.2015.00098

PMid:25798138

56. Lok J, Leung W, Murphy S, Butler W, Noviski N, Lo EH Intracranial hemorrhage: Mechanisms of secondary brain injury. Intracerebral Hemorrhage Res. 2011;111:63-9. http://doi. org/10.1007/978-3-7091-0693-8_11

PMid:21725733

57. Vermi CC, Davila A Jr., Balian S, Sims CA, Diamond SL. Platelet dysfunction during trauma involves diverse signaling pathways and an inhibitory activity in patient-derived plasma. J Trauma Acute Care Surg. 2019;86(2):250-9. http://doi.org/10.1097/ TA.0000000000002140 PMid:30531331

58. Castellino FJ, Chapman MP, Donahue DL, Thomas S, Moore EE, Wohlauer MV, et al. Traumatic brain injury causes platelet adenosine diphosphate and arachidonic acid receptor inhibition independent of hemorrhagic shock in humans and rats. J Trauma Acute Care Surg. 2014;76(5):1169-76. http://doi. org/10.1097/TA.0000000000000216

PMid:24747445

59. Donahue DL, Beck J, Fritz B, Davis P, Sandoval-Cooper MJ, Thomas SG, et al. Early platelet dysfunction in a rodent model of blunt traumatic brain injury reflects the acute traumatic coagulopathy found in humans. J Neurotrauma. 2014;31(4):404-10. http://doi.org/10.1089/neu.2013.3089 PMid:24040968

60. Nekludov M, Bellander BM, Blomback M, Wallen HN. Platelet dysfunction in patients with severe traumatic brain injury. J Neurotrauma. 2007;24(11):1699-706. http://doi.org/10.1089/ neu.2007.0322

PMid: 18001200

61. Brohi K, Cohen M, Ganter M, Schultz MJ, Levi M, Mackersie RC et al. Acute coagulopathy of trauma: Hypoperfusion induces systemic anticoagulation and hyperfibrinolysis. J Trauma. 2008;64(5):1211-7. http://doi.org/10.1097/ TA.0b013e318169cd3c

PMid: 18469643

62. Davis PK, Musunuru H, Walsh M, Cassady R, Yount R, Losiniecki $\mathrm{A}$, et al. Platelet dysfunction is an early marker for traumatic brain injury-induced coagulopathy. Neurocrit Care. 2012;18(2):201-8. http://doi.org/10.1007/s12028-012-9745-6 PMid:22847397

63. Huber-Lang $M$, Huber-Lang $M$, Sarma JV, Zetoune FS, Rittirsch D, Neff TA, et al. Generation of C5a in the absence 
of C3: A new complement activation pathway. Nat Med. 2006;12(6):682-7. http://doi.org/10.1038/nm1419 PMid: 16715088

64. Ramsey M, Fabian T, Shahan C, Sharpe JP, Mabry SE, Weinberg JA, et al. A prospective study of platelet function in trauma patients. J Trauma Acute Care Surg. 2016;80(5):726-33. http://doi.org/10.1097/TA.0000000000001017 PMid:26895088

65. SchererRU,SpangenbergP. Procoagulantactivityin patients with isolated severe head trauma. Crit Care Med. 1998;26(1):149-56. http://doi.org/10.1097/00003246-199801000-00031 PMid:9428558

66. Halpern $\mathrm{CH}$, Reilly PM, Turtz AR, Stein SC. Traumatic coagulopathy: The effect of brain injury. J Neurotrauma. 2008;25(8):997-1001. http://doi.org/10.1089/neu.2008.0548 PMid:18687038

67. Maegele M. Coagulopathy after traumatic brain injury: Incidence, pathogenesis, and treatment options. Transfusion. 2013;53(Suppl 1):28S-37S. http://doi.org/10.1111/trf.12033 PMid:23301970

68. Keimowitz RM, Annis BL. Disseminated intravascular coagulation associated with massive brain injury. J Neurosurg 1973;39(2):178-80. http://doi.org/10.3171/jns.1973.39.2.0178 PMid:4719695

69. Pathak A, Dutta S, Marwaha N, Singh D, Varma N, Mathuriya SN. Change in tissue thromboplastin content of brain following trauma. Neurol India. 2005;53(2):178-82. http://doi. org/10.4103/0028-3886.16404 PMid: 16010055

70. Aksu K, Donmez A, Keser G. Inflammation-induced thrombosis: Mechanisms, disease associations and management. Curr Pharm Des. 2012;18(11):1478-93. http://doi. org/10.2174/138161212799504731 PMid:22364132

71. Colkesen $\mathrm{Y}$, Muderrisoglu $\mathrm{H}$. The role of mean platelet volume in predicting thrombotic events. Clin Chem Lab Med. 2012;50(4):631-4. http://doi.org/10.1515/CCLM.2011.806 PMid:22112054

72. Lapetina EG, Cuatrecasas P. Rapid inactivation of cyclooxygenase activity after stimulation of intact platelets. Proc natl Acad Sci U S A. 1979;76(1):121-5. http://doi.org/10.1073/ pnas.76.1.121

PMid:218191

73. Lippi G, Favaloro EJ, Cervellin G. Massive posttraumatic bleeding: epidemiology, causes, clinical features, and therapeutic management. Semin Thromb Hemost. 2012;39(1):83-93. http:// doi.org/10.1055/s-0032-1328936 PMid:23086540

74. Lippi G, Cervellin G. Disseminated intravascular coagulation in trauma injuries. Semin Thromb Hemost. 2010;36(4):378-87. http://doi.org/10.1055/s-0030-1254047 PMid:20614390

75. Jacoby RC, Owings JT, Holmes J, Battistella FD, Gosselin RC, Paglieroni TG. Platelet activation and function after trauma. J Trauma. 2001;51(4):639-47. http://doi. org/10.1097/00005373-200110000-00003

PMid:11586152

76. Chen H, Li M, Liu L, Dang X, Zhu D, Tian G. Monocyte/ lymphocyte ratio is related to the severity of coronary artery disease and clinical outcome in patients with non-ST-elevation myocardial infarction. Medicine. 2019;98(26):e16267. http://doi. org/10.1097/MD.0000000000016267 PMid:31261596

77. Ji H, Li Y, Fan Z, Zuo B, Jian X, Li L, et al. Monocyte/lymphocyte ratio predicts the severity of coronary artery disease: $A$ syntax score assessment. BMC Cardiovasc Dis. 2017;17(1):90. http:// doi.org/10.1186/s12872-017-0507-4

PMid:28359298

78. Jan H, Yang W, Ou C. Combination of the preoperative systemic immune-inflammation index and monocyte-lymphocyte ratio as a novel prognostic factor in patients with upper-tract urothelial carcinoma. Ann Surg Oncol. 2018;26(2):669-84. http://doi. org/10.1245/s10434-018-6942-3

PMid:30374917

79. Sheng J, Li T, Zhuang D, Cai S, Yang J, Ding F, et al. The monocyte-to-lymphocyte ratio at hospital admission is a novel predictor for acute traumatic intraparenchymal hemorrhage expansion after cerebral contusion. Mediat Inflamm. 2020;2020:5483981. https://doi.org/10.1155/2020/5483981

80. Ding KQ, Lai ZH, Zhang Y, Yang GY, He JR, Zeng LL. Monocyteto-lymphocyte ratio is associated with depression 3 months after stroke. Neuropsychiatr Dis Treat. 2021;17:835-45. http://doi. org/10.2147/NDT.S299462 PMid:33776439

81. Han J, Park T, Cho S, Joh J, Ahn H. Increased mean platelet volume and mean platelet volume/platelet count ratio in Korean patients with deep vein thrombosis. Platelets. 2012;24(8):590-3. http://doi.org/10.3109/09537104.2012.748187 PMid:23215785

82. Lippi G, Carbucicchio A, Benatti M, Cervellin G. The mean platelet volume is decreased in patients with mild head trauma and brain injury. Blood Coagul Fibrinolysis. 2013;24(7):780-3. http://doi.org/10.1097/MBC.0b013e328361422b PMid:24056292

83. Robbins G, Barnard DL. Mean platelet volume changes in infection. J Clin Pathol. 1983;36(11):1320. http://doi.org/10.1136/ jсp.36.11.1320-a

PMid:6630582

84. Kapsoritakis A, Koukourakis M, Sfiridaki A, Potamianos SP, Kosmadaki MG, Koutroubakis IE, et al. Mean platelet volume: A useful marker of inflammatory bowel disease activity. Am J Gastroenterol. 2001;96(3):776-81. http://doi. org/10.1111/j.1572-0241.2001.03621.x PMid: 11280550

85. Tuncel T, Uysal P, Hocaoglu A, Erge DO, Karaman O, Uzuner N. Change of mean platelet volume values in asthmatic children as an inflammatory marker. Allergol Immunopathol. 2012;40(2):104-107. http://doi.org/10.1016/j.aller.2011.03.007 PMid:21621316

86. Ulasli S, Ozyurek B, Yilmaz E, Ulubay G. Mean platelet volume as an inflammatory marker in acute exacerbation of chronic obstructive pulmonary disease. Polish Arch Int Med. 2012;122(6):284-90. http://doi.org/10.20452/pamw.1284 PMid:22576316

87. Thompson CB, Jakubowski JA, Quinn PG, Deykin D, Valeri CR. Platelet size and age determine platelet function independently. Blood. 1984;63(6):1372-5.

PMid:6722354

88. Cho S, Yang J, You E, Kim BH, Shim J, Lee HJ, et al. Mean platelet volume/platelet count ratio in hepatocellular carcinoma. Platelets. 2012;24(5):375-7. http://doi.org/10.3109/09537104.2 012.701028

PMid:22835043

89. Schnüriger $B$, Inaba $K$, Abdelsayed $G$, Lustenberger $T$, Eberle BM, Barmparas G, et al. The impact of platelets on the progression of traumatic intracranial hemorrhage. J Trauma Injury Infect Crit Care. 2010;68(4):881-5. http://doi.org/10.1097/ TA.0b013e3181d3cc58

PMid:20386283 
90. Carrick MM, Tyroch AH, Youens CA, Handley T. Subsequent development of thrombocytopenia and coagulopathy in moderate and severe head injury: Support for serial laboratory examination. J Trauma. 2005;58(4):725-30. http://doi. org/10.1097/01.ta.0000159249.68363.78

\section{PMid:15824648}

91. Cortiana M, Zagara G, Fava S, Seveso M. Coagulation abnormalities in patients with head injury. J Neurosurg. 1986;30(3):133-8.

PMid:3783267

92. Auer L. Disturbances of the coagulatory system in patients with severe cerebral trauma. Acta Neurochir. 1978;43(1-2):51-9. http://doi.org/10.1007/BF01809225

PMid:707171

93. Ray B, Tinsley L, Ford L, Thompson DM, Sidorov EV, Bohnstedt BN. Trends of platelet volume index predicts delayed cerebral ischemia after subarachnoid hemorrhage. World Neurosurg. 2018;111:e624-31. http://doi.org/10.1016/j. wneu.2017.12.131

PMid:29292187

94. Ayinbuomwan W, Idogun E, Iribhogbe P. High sensitivity C-reactive protein in patients with acute injuries. IOSR J Defense Model Simul. 2015;14(6):94-8. http://doi.org/10.1016/j. ahj.2019.06.019

PMid:31382219

95. Wolbink GJ, Brouwer MC, Buysmann S, Ten Berge IJ, Hack CE. CRP-mediated activation of complement in vivo: Assessment by measuring circulating complement-C-reactive protein complexes. J Immunol. 1996;157(1):473-9.

PMid:8683153

96. Hicks PS, Saunero-Nava L, Du Clos TW, Mold C. Serum amyloid $P$ component binds to histones and activates the classical complement pathway. J Immunol. 1992;149(11):3689-94.

PMid: 1431140

97. Gabay C, Kushner I. Acute-phase proteins and other systematic responses to inflammation. N Engl J Med. 1999;340(6):448-54. http://doi.org/10.1056/NEJM199902113400607

\section{PMid:9971870}

98. Thompson D, Pepys MB, Wood SP. The physiological structure of human C-reactive protein and its complex with phosphocholine. Structure. 1999;7(2):169-77. http://doi. org/10.1016/S0969-2126(99)80023-9

PMid:10368284

99. Di Napoli M, Parry-Jones AR, Smith CJ, Hopkins SJ, Slevin M, Masotti $\mathrm{L}$, et al. C-reactive protein predicts hematoma growth in intracerebral hemorrhage. Stroke. 2014;45(1):59-65. http://doi. org/10.1161/STROKEAHA.113.001721

PMid:24262327

100. Ridker PM. From CRP to IL-6 to IL-1: Moving upstream to identify novel targets for atheroprotection. Circ Res. 2016;118(1):145-56. http://doi.org/10.1161/CIRCRESAHA.115.306656 PMid:26837745

101. Vermiere S, Van Assche G, Rutgeerts P. The role of c-reactive protein as an inflammatory marker in gastrointestinal diseases. Nat Clin Pract Gastroenterol Hepatol. 2005;2(12):580-6. http:// doi.org/10.1038/ncpgasthep0359

PMid:16327837

102. Bomba GI, Maliawan S, Mahadewa TG. High serum C-reactive protein as predictor of systemic inflammatory response syndrome in severe head injury patients. Bali Med J. 2013;2(1):38-41.

103. Xu LB, Yue JK, Korley F, Puccio AM, Yuh EL, Sun X, et al. Highsensitivity $\mathrm{C}$-reactive protein is a prognostic biomarker of six month disability after traumatic brain injury: Results from the TRACK-TBI study. J Neurotrauma. 2021;38(7):918-27. http:// doi.org/10.1089/neu.2020.7177

PMid:33161875

104. Su S, Xu W, Li M, Zhang L, Wu YF, Yu F, et al. Elevated C-reactive protein levels may be a predictor of persistent unfavourable symptoms in patients with mild traumatic brain injury: A preliminary study. Brain Behav Immunity. 2014;98(1):111-7. http://doi.org/10.1016/j.bbi.2014.01.009

PMid:24456846

105. Carabias CS, Gomez PA, Panero I, Eiriz C, Castano-Leon AM, Egea $\mathrm{J}$, et al. Chitinase-3-like protein 1 , serum amyloid $\mathrm{A} 1$, $\mathrm{c}$-reactive protein, and procalcitonin are promising biomarkers for intracranial severity assessment of traumatic brain injury: Relationship with Glasgow coma scale and computed tomography volumetry. World Neurosurg. 2020;134:e120-43. http://doi.org/10.1016/j.wneu.2019.09.143

PMid:31606503

106. Anada RP, Wong KT, Jayapalan JJ, Hashim OH, Ganesan D. Panel of serum protein biomarkers to grade the severity of traumatic brain injury. Electrophoresis. 2018;39(18):2308-15. http://doi.org/10.1002/elps.201700407 PMid:29570807

107. Sogut O, Guloglu C, Orak M, Sayhan MB, Gokdemir MT, Ustundag M, et al. Trauma scores and neuron-specific enolase, cytokine and c-reactive protein levels as preditors of mortality in patientswithbluntheadtrauma.JIntMedRes.2010;38(5):1708-20. http://doi.org/10.1177/147323001003800516

\section{PMid:21309485}

108. Fountas KN, Tasiou A, Kapsalaki EZ, Paterakis KN, Grigorian AA, Lee GP, et al. Serum and cerebrospinal fluid C-reactive protein levels as predictors of vasospasm in aneurysmal subarachnoid hemorrhage. Neurosurg Focus. 2009;26(5):E22. http://doi. org/10.3171/2009.2.FOCUS08311

PMid: 19409001

109. Rothoerl RD, Axmann C, Pina AL, Woertgen C, Brawanski A Possible role of the c-reactive protein and white blood cell count in the pathogenesis of cerebral vasospasm following aneurysmal subarachnoid hemorrhage. J Neurosurg Anesthesiol. 2006;18(1):68-72. http://doi.org/10.1097/01. ana.0000181693.30750.af PMid:16369143

110. Bray C, Bell LN, Liang H, Haykal R, Kaiksow F, Mazza JJ, et al. Erythrocyte sedimentation rate and C-reactive protein measurements and their relevance in clinical medicine. WMJ. 2016;115(6):317-21. PMid:29094869

111. Lapić I, Padoan A, Bozzato D, Plebani M. Erythrocyte sedimentation rate and c-reactive protein in acute inflammation. Am J Clin Pathol. 2019;153(1):14-29. http://doi.org/10.1093/ ajcp/aqz142 PMid:31598629

112. Alende-Castro V, Alonso-Sampedro M, Vazquez-Temprano N, Tunez C, Rey D, Garcia-Iglesias C, et al. Factors influencing erythrocyte sedimentation rate in adults. Medicine. 2019;98(34):e16816. http://doi.org/10.1097/ MD.0000000000016816 PMid:31441853

113. Zaremba J, Skrobanski P, Losy J. Acute ischaemic stroke increases the erythrocyte sedimentation rate, which correlates with early brain damage. Folia Morphol (Warsz). 2004;63(4):373-6.

PMid:15712129 